\title{
Atherosclerosis in Youth
}

\section{小児期からの動脈硬化予防*}

大国真 彦** 岡田知 雄**

近年日本人小児において，血清脂質レベルが上 昇し，虚血性心疾患の危険因子を数多く保有する ものが増加していることが明らかにされている. また 10 歳代の小児の大部分に病理学的に動脈硬 化性病変が認められることは, 動脈硬化の予防 は小児期から始めるべきであることを示してい る。

一方小児の血清脂質値にはかなりの個体差があ り, 性差がある. 高值を示す者が増加している一 方で, 総コレステロールが低すぎる值を示す例も あり，多くの要因が関与している.

食事の影響が大きいことは言うまでもないが， 環境要因と習慣因子の影響も大きい. 著者らは 6 組の一卵性双生児の高校生の血清脂質を調べたが, 2 組において総コレステロール值に $10 \mathrm{mg} / \mathrm{d} l$ 以 上の差を認め, 2 組に HDL コレステロール值に $8 \mathrm{mg} / \mathrm{d} l$ 以上の差を認めている.

とくに影響が大きいのは運動で, 小学生におい てスポーツテストによる運動能力と血清脂質の関 係を検討したところ, 運動能力が優秀な者は総コ レステロール值も高いが，それが HDL コレステ ロールにより押し上げられたものであり, 動脈硬 化指数は運動能力のある者に有意に低いことが明 らかにされた (Fig. 1). これらの生徒の食事につ いても調べたが, 運動能力のあるものは動物性脂 肪を多くとっても動脈硬化指数が低いことが示さ れた.このことは小児に運動の習慣をつけること が動脈硬化予防の見地からきわめて重要であるこ とを示すものと考えられた。

* 1987 年 12 月, 日本動脈硬化学会 昭和 62 年度冬季 大会に扔いて発表

** 日本大学医学部小児科学教室

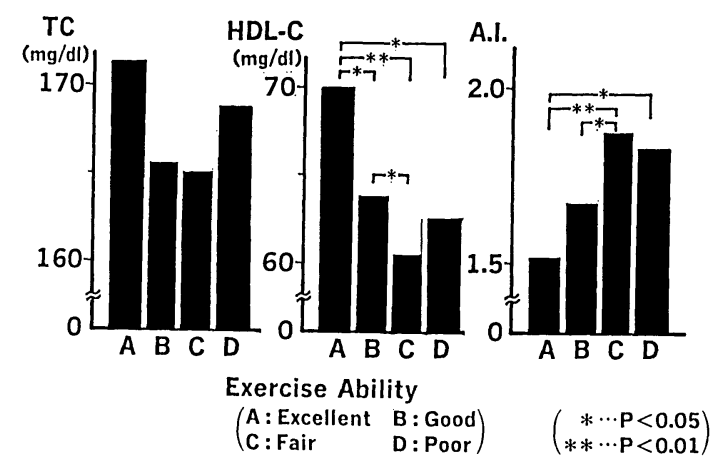

Fig. 1 The effects of exercise ability on serum lipids in school-age boys.

小児期の高脂血症が成人における高脂血症にど の程度関連するかについて検討した成績は少ない。 著者らは 6〜12 歳および 7 13 歳の 6年間の同一 人における血清脂質の変化を追跡したが, 総コレ ステロール值, HDL コレステロール值および動 脈硬化指数のいずれもが有意の相関を示した.

このことより, 成人病の予防は小児期より開始 すべきであり，とくに幼坚期における生活の正し い習慣づけが重要であると考えられた。

小児におけるリノール酸の血清脂質に及ぼす影 響を検討したが，高リノール酸食を 4 週与えると 総コレステロール值は有意に低下し，HDL コレ ステロール值は有意に上昇し，動脈硬化指数が有 意に低下することが示された.

小児期からの動脈硬化予防には，ハイリスク児 の発見と指導, および一般の保健教育が重要であ る. 日本学校保健会において, 保健教育のための パンフレットを作成し，普及中である．またハイ リスク児のスクリーニングシステムについても検 討し，具体的な指導基準を定め，一部の地域にお いて試験的に実施しているところである。 